\title{
Geotechnical Investigations and Estimation of Earthquakes Factors at an Industrial Qift City, Qena, Egypt
}

\author{
Hesham A. H. Ismaiel \\ Geology Department, Faculty of Science, South Valley University, Qena, Egypt \\ Email: heshahmed@yahoo.com
}

How to cite this paper: Ismaiel, H. A. H. (2018). Geotechnical Investigations and Estimation of Earthquakes Factors at an Industrial Qift City, Qena, Egypt. Journal of Geoscience and Environment Protection, 6, 133-145.

https://doi.org/10.4236/gep.2018.612010

Received: August 9, 2018

Accepted: December 22, 2018

Published: December 25, 2018

Copyright $\odot 2018$ by author and Scientific Research Publishing Inc. This work is licensed under the Creative Commons Attribution International License (CC BY 4.0).

http://creativecommons.org/licenses/by/4.0/

\begin{abstract}
The present work dealt with the estimation of geotechnical parameters and earthquakes factors of poultry feed factory project constructing at an industrial Qift city, Qena, Egypt. The geotechnical parameters were including gradation parameters, shear velocity (Vs), shear parameters (frictional angle and cohesion), and allowable bearing capacity. The earthquakes factors were including soil coefficient (S), limits of constant value for elastic response spectrum $\left(\mathrm{T}_{\mathrm{B}}\right.$ and $\left.\mathrm{T}_{\mathrm{C}}\right)$, and specified value for begin of the constant displacement spectrum $\left(\mathrm{T}_{\mathrm{D}}\right)$. The present study was interested also in an estimation of design ground acceleration $\left(\mathrm{a}_{\mathrm{g}}\right)$. To achieve these objectives, five mechanical wash boreholes were conducted at ten meter depth. Fifty disturbed samples were collected. Geotechnical laboratory tests were carried out like grain size analyses, direct shear box, and shear velocity (Vs). Standard penetration test (SPT) as geotechnical field test was conducted. The results showed that the studied soils were classified as well graded and poorly graded sands (SP and $\mathrm{SW}$ ) according to the unified soil classification system (USCS). The earthquakes factors including $S, T_{B}, T_{C}$, and $T_{D}$ were $1.80,0.10,0.30$, and 1.20 respectively. The $a_{\mathrm{g}}$-value of the studied area was 0.10 . According to Egyptian code for vibration and dynamic load foundations, the studied project area was classified as low potential seismic. According to Egyptian code for shallow foundation, the allowable bearing capacity of the studied sands ranging from 1.5 to $3 \mathrm{~kg} / \mathrm{cm}^{2}$ at shallow foundation width must be not less than one meter. Shallow foundations like isolated footing or structural mat were recommended.
\end{abstract}

\section{Keywords}

Earthquakes Factors, Standard Penetration Test, Shear Velocity 


\section{Introduction}

Industrial Qift city is one of the new industrial cities in Qena governorate; it was constructed to collect all the industrial activates in Qena region to encourage the investment and to contribute in the development of Qena city (Figure 1 \& Figure 2). The local geological conditions and shallow shear wave velocity structure of a site have a significant effect on earthquake ground motion. This effect is known as the site effect and may cause amplification of earthquake ground motion in frequency ranges unfavorable for buildings and structures especially in the presence of soft sedimentary covers overlying the bedrock (Mostafa et al., 2016). The seismic activity of Egypt is due to the interaction and the relative motion between the plates of Eurasia, Africa and Arabia. Within the last decade, some areas in Egypt have been struck by significant earthquakes causing considerable damage. Such events were interpreted as the result of this interaction (Sawires, et al., 2016). The present work is a try to deep understand the site effect including the soil type and its geotechnical behavior and its role in the seismic hazards assessment of the building construction at the study area. The construction of large projects and factories needs to evaluate the geotechnical behavior of the soils in the study area as well as to estimate the seismic hazard including the earthquakes factors and design ground acceleration. The present study area was investigated to determine the suitability of the study area and the soils to construct poultry feed factor at the industrial Qift city. The factory was designed only of two floors; it is considered as lightly loaded building (Figure 3).

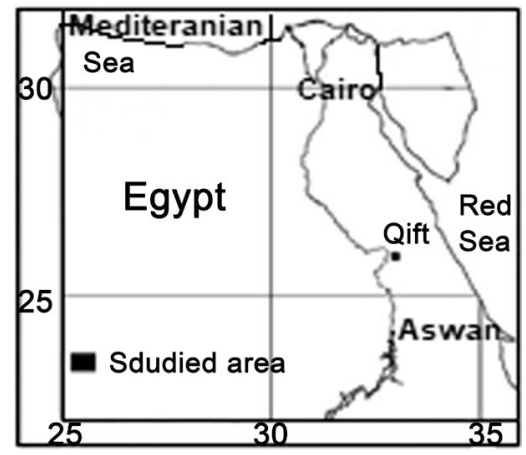

Figure 1. Location map of the studied area, modified after (Ismaiel, 2013).

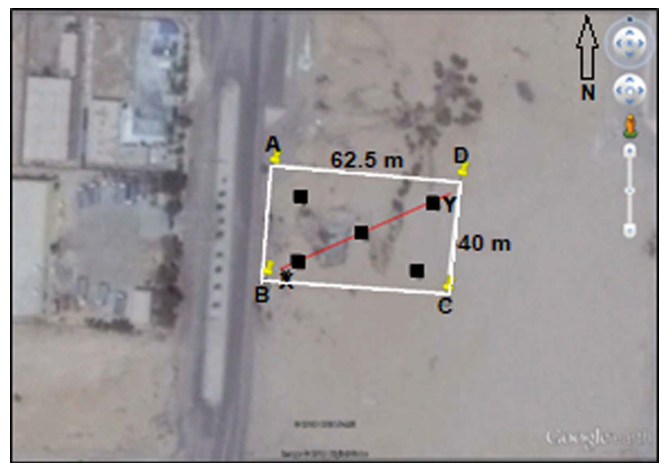

Figure 2. Land sate image of the studied project. 


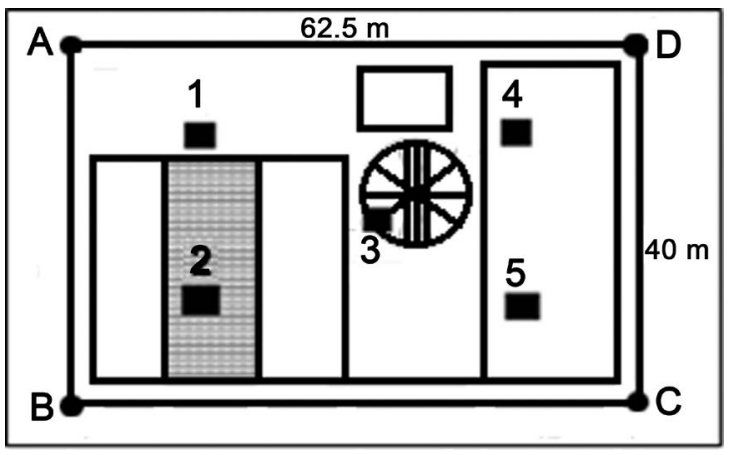

Figure 3. Layout of the studied project illustrated the boreholes (B1 to B5) distribution and the corner points $(\mathrm{A}, \mathrm{B}, \mathrm{C}$, and $\mathrm{D})$.

\subsection{Previous Works}

Little of earthquakes assessment and geological hazards researches were conducted on the studied area by (Mostafa et al., 2016), (Sawires et al., 2016), and (Deif et al., 2011). The studied area was geologically investigated by many of authors. Sedimentlogical and stratigraphical investigations were conducted by (Sabry, 1968), (Said \& Sabry, 1964), (Krasheninnikov \& Penikarvo, 1964), (Hermina \& Issawi, 1969), (Philiobbos, 1969), (Issawi, 1972), (Issawi et al., 1978), and (Abd El-Rahman, 1980). Structural and tectonics studies were carried out by (Said, 1962), (Abd El-Razik \& Razvaliaev, 1972), and (Abdalla et al., 1977). Geomorphological and geomorphological hazards works were achieved by (Said, 1971), (Youssef et al., 2009), and (El-Etr et al., 1979). Surveying works were done by (Makhloof et al., 2013). Engineering geophysical researches were conducted by (Ismail, 2000), and (Basher, 2003). Few geotechnical studies were carried out by (Wuest \& McLane, 2000), (Ismaiel et al., 2011), (Ismaiel et al., 2012), and (Ismaiel, 2013).

\subsection{Scopes of the Present Work}

The present study deals with the estimation of the geotechnical parameters of the studied soils including gradation parameters, shear parameters $(\phi \& \mathrm{Cu})$, and shear velocity (Vs) to calculate the earthquakes factors of the studied soils and the design ground acceleration $\left(\mathrm{a}_{\mathrm{g}}\right)$. That helps in determination of the seismic suitability of the studied area for constructing the poultry feed factory at an industrial Qift city. It also deals with calculation the allowable bearing capacity of the studied soils. The earthquakes factors are including soil coefficient (S), limits of constant value for elastic response spectrum $\left(T_{B}\right.$ and $\left.T_{C}\right)$, and specified value for begin of the constant displacement spectrum $\left(T_{D}\right)$. These earthquakes factors help the civil engineer to calculate the total base shear due to earthquakes (if happened) to design the project foundations to avoid the possible seismic damages.

\subsection{Geological Setting}

The investigated area is located at the east of Qift city, $20 \mathrm{~km}$ south of Qena city. The coordinates of the studied area illustrated in Table 1 . The area has a wide 
variety of sediments belonging to the Upper Cretaceous-Lower Tertiary succession as well as the Pliocene-Recent sediments (Ismail, 2000). It is covered by Quaternary sediments in the form of Nile silt, Wadi deposits, and pre-Nile sediments. The studied soils are representative of pre-Nile sands named Qena Sand Formation (Pleistocene age). The area is surrounded by Pliocene deposits and Dawi Formation at both east and southeast directions. The distribution of the studied Quaternary sediments is showed in Figure 4. The studied area is located in a transitional zone between the eastern desert and the Nile valley. It is characterized by a simple topography follows the regional northwest slope towards the Nile. The area around the industrial Qift city is dissected by many large wadies like Wadi Matuli to the east and Wadi Khozam to the south. The courses of these wadis are running from the southeast to the northwest direction depending on the direction of dominant fault strikes and that pointed sure to that these wadis have structurally controlled origin. The study area is located at the recently stable tectonic zone.

\section{Materials and Methods}

\subsection{Materials}

Fifty disturbed samples were collected from five (B1 to B5) wash mechanical drilling boreholes (10 $\mathrm{m}$ depth); one sample was selected in each one meter

Table 1. The coordinates of the studied area. (A, B, C, and D (corners points of the studied area)).

\begin{tabular}{ccc}
\hline East & North & Corner points \\
\cline { 1 - 2 } World Coordinate System (WGS 84) & & A \\
$32^{\circ} 52^{\prime} 54.8^{\prime \prime}$ & $25^{\circ} 58^{\prime} 42.3^{\prime \prime}$ & $\mathrm{B}$ \\
$32^{\circ} 52^{\prime} 54.8^{\prime \prime}$ & $25^{\circ} 58^{\prime} 41.1^{\prime \prime}$ & $\mathrm{C}$ \\
$32^{\circ} 52^{\prime} 57.0^{\prime \prime}$ & $25^{\circ} 58^{\prime} 40.9^{\prime \prime}$ & $\mathrm{D}$ \\
$32^{\circ} 52^{\prime} 57.1^{\prime \prime}$ & $25^{\circ} 58^{\prime} 42.2^{\prime \prime}$ & \\
\hline
\end{tabular}

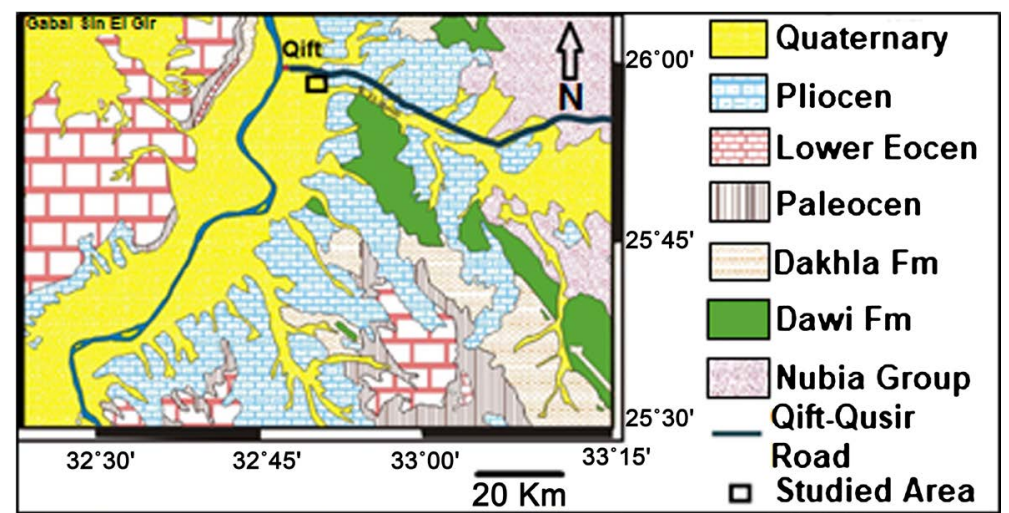

Figure 4. Geological map of the studied area modified after (Egyptian Geological Survey and Minning Authority, 1978). 
depth (Figure $2 \&$ Figure $3 \&$ Figure 5). The studied soils were belonging to the pre-Nile sediments named Qena Sand Formation and having Quaternary age.

\subsection{Methods}

Subsurface exploration wash mechanical drilling according to (Egyptian Code, Part 2, 2001) was carried out to achieve five (B1 to B5) boreholes (10 m depth) and to collect the studied specimens (Figure 6). One geotechnical test in the field during the drilling process named standard penetration test (SPT) was conducted according to (Egyptian Code, Part 2, 2001) to calculate the frictional angle $(\phi)$ and the cohesion $(\mathrm{Cu})$ of the studied sand samples. Three geotechnical tests in the laboratory including grain size analysis, direct shear box (Egyptian Code, Part 2, 2001), and shear velocity (Vs) using JAMES instrument (Yesiller et al., 2001) were conducted on the studied sand samples to measure the shear parameters and the shear velocity values which help to determine the soil class (Egyptian Code, Part 6, 2001).

\section{Results}

\subsection{Wash Mechanical Drilling Results}

Correlation between three boreholes data (B2, B3, and B4) was carried out to create a vertical cross-section of the studied area in XY-direction (Figure 2). The lithology of B1 and B2 was similar to B3.The results showed that the area composed mainly of sands. From the surface to one to two meter depth, the soils composed of poorly graded sands, and from two meter depth to ten meter depth composed of well graded sands (Figure 5). There was no underground water until the end of drilling depth (10 meter) of the studied boreholes. The sands samples at the studied cross-section were dry that means the pore water pressure

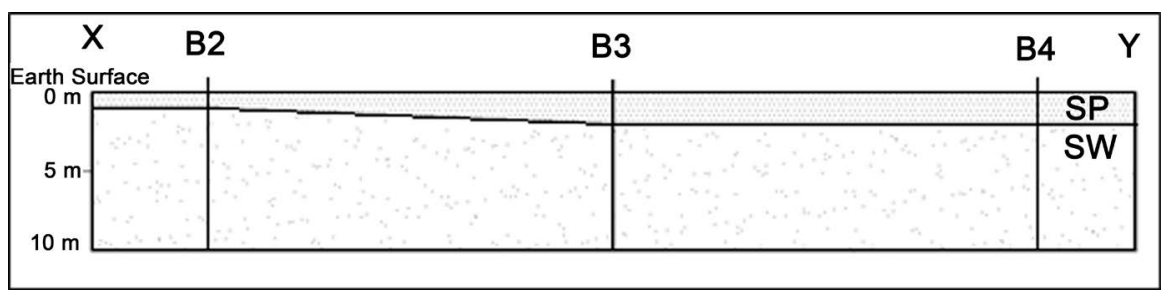

Figure 5. Cross-section in the studied area along the XY-direction.

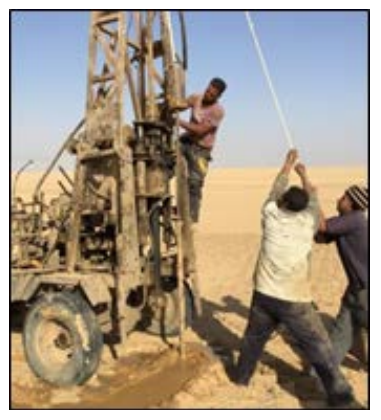

Figure 6. Standard penetration test (SPT) during wash mechanical drilling. 
of the studied sands equal to zero.

\subsection{Grain Size Analyses Results}

Figure 7 showed the grain size distribution curves of the studied sand samples. The studied sand samples composed mainly of sand size ranging from $92 \%$ to $95 \%$ and trace of silt size ranging from $2 \%$ to $5 \%$ as well as trace of fine gravels ranging from $3 \%$ to $5 \%$. The results of the grain size distribution test of the studied soils showed that the sand samples at the five studied boreholes were classified as poorly graded sands (SP) at the first two meters depth where the gradation parameters of the studied sands including coefficient of uniformity were less than 6 according to unified soil classification system (USCS). But the sands collected from two meter to ten meter depth were classified as well graded sands (SW) where the gradation parameters of the studied sands including coefficient of uniformity were more than 6 according to USCS.

\subsection{Shear Wave Velocity (Vs) Results}

The results pointed to that the shear wave velocities (Vs) of the studied sand samples compacted at the maximum modified proctor density were ranging from 155 to $176 \mathrm{~m} / \mathrm{s}$.

\subsection{Direct Shear Box Results}

The direct shear box test was carried out to determine the frictional angle $(\phi)$

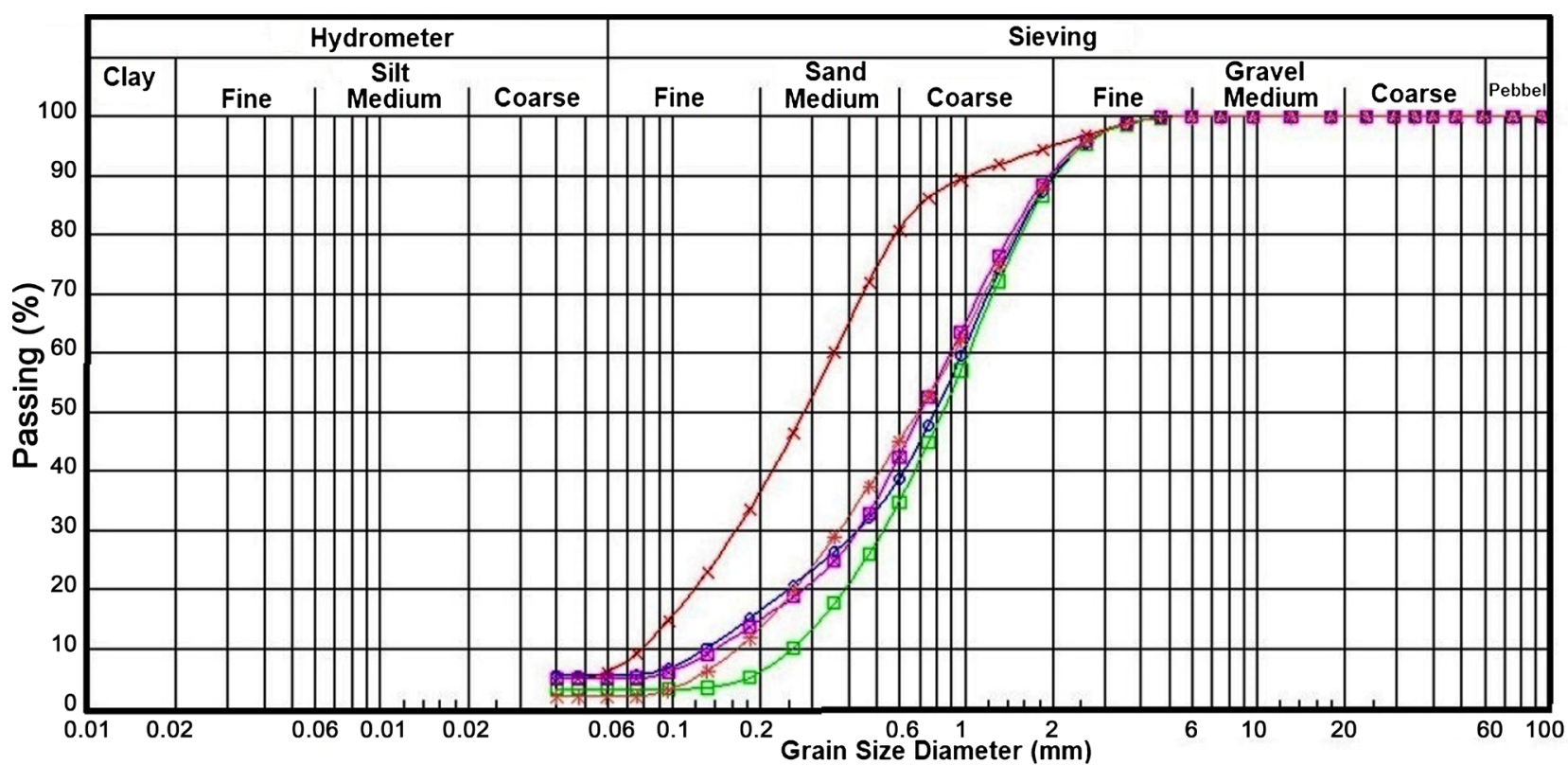

\begin{tabular}{|l|c|c|c|c|c|}
\hline Symbol & $*$ & $*$ & $*$ & $*$ & $*$ \\
\hline Soil Type & SW & SP & SW & SW & SW \\
\hline Depth & $1 \mathrm{~m}$ & $2 \mathrm{~m}$ & $4 \mathrm{~m}$ & $9 \mathrm{~m}$ & $3 \mathrm{~m}$ \\
\hline Cu/Cc & $7.6 / 1.5$ & $4.6 / 1.0$ & $4.0 / 1.0$ & $6.4 / 1.5$ & $5.5 / 0.6$ \\
\hline Borehole & B1 & B2 & B 3 & B4 & B5 \\
\hline
\end{tabular}

Figure 7. Grain size distribution curves of the studies sand samples. 
and the cohesion $(\mathrm{Cu})$ of the collected soil samples (in the laboratory).

Three representatives and samples were collected from borehole no. 2, 3, and 4 and tested according to (Egyptian Code, Part 2, 2001). The results were listed below in Table 2. The results showed that the friction angle values of the studied sandy soils ranging from $32^{\circ}$ to $40^{\circ}$. The frictional angels of the sand at B2, B3, and $\mathrm{B} 4$ were $32^{\circ}, 35^{\circ}$, and $40^{\circ}$ respectively. The results illustrated that the cohesion values $(\mathrm{Cu})$ of the studied sandy soils equal to zero.

\subsection{Standard Penetration Test (SPT) Results}

Standard penetration tests (SPT) were conducted (in the field), associated with the wash mechanical drilling process, on the studied sands beds according to (Egyptian Code, Part 2, 2001) using blow weight equal to $62.5 \mathrm{~kg}$ and drop height equal to $76 \mathrm{~cm}$, the blow numbers $\left(\mathrm{N}_{\text {spt }}\right)$ recorded each $30 \mathrm{~cm}$ penetration. SPT-values were ranged from 9 to more than 45 blow number each $30 \mathrm{~cm}$ penetration. Generally the surface loose poorly graded sands (at the first two meters depth) have the lowest values ranging from 9 to 10. SPT-values were increased with increasing the depth and the compaction of the sands. The greatest values were ranging from 30 to 45 at about 8 to 10 meters depth and described as dense sands. Some intermediate SPT-values were ranging from 10 to 30 and described as medium dense sands (at depth ranging from 3 to 7 meters). The relationship between the SPT-values, the relative density, and the frictional angle of the soils according to the Egyptian code showed in Table 3.

\section{Estimation of Earthquakes Factors}

Earthquakes factors were estimated according to (Egyptian Code, Part 6, 2001). There are six activity zones in Egypt arranged from the first zone to the fifth B

Table 2. Frictional angle $(\phi)$ and cohesion values $(\mathrm{Cu})$ of the studied sand samples.

\begin{tabular}{cccccc}
\hline Sample No. & Location & Depth $(\mathrm{m})$ & Soil Type & Frictional Angel $(\phi)$ & Cohesion $(\mathrm{Cu})$ \\
\hline 1 & B2 & 1 & SP & $32^{\circ}$ & 0.00 \\
2 & B3 & 2 & SP & $35^{\circ}$ & 0.00 \\
3 & B4 & 3 & SW & $40^{\circ}$ & 0.00 \\
\hline
\end{tabular}

Table 3. The relationship between the SPT-values, the relative density, and the frictional angle of the soils after (Egyptian Code, Part 2, 2001).

\begin{tabular}{cccc}
\hline \multirow{2}{*}{ Frictional Angle $(\phi)^{\circ}$} & \multicolumn{2}{c}{ Relative Density } & $\begin{array}{c}\text { SPT-valued }\left(\mathrm{N}_{\mathrm{spt}}\right) \\
\text { Blow Numer/30 cm }\end{array}$ \\
\cline { 2 - 3 } $27-30$ & Value & Description & $0-4$ \\
$30-32$ & $0-0.15$ & very loose & $4-10$ \\
$32-36$ & $0.15-0.35$ & loose & $10-30$ \\
$36-40$ & $0.35-0.65$ & medium & $30-50$ \\
$>40$ & $0.65-0.85$ & dense & $>50$ \\
\hline
\end{tabular}


zone. The study area at Qena city is located in the first seismic zone (zone no. 1) (Figure 8 \& Table 4). The value of design ground acceleration $\left(a_{g}\right)$ at seismic zone no. 1 was $0.10 \mathrm{~g}$ (Table 5). The geotechnical tests results showed that the soil layer type of the study area was class $\mathrm{D}$, where the number of blow each 30

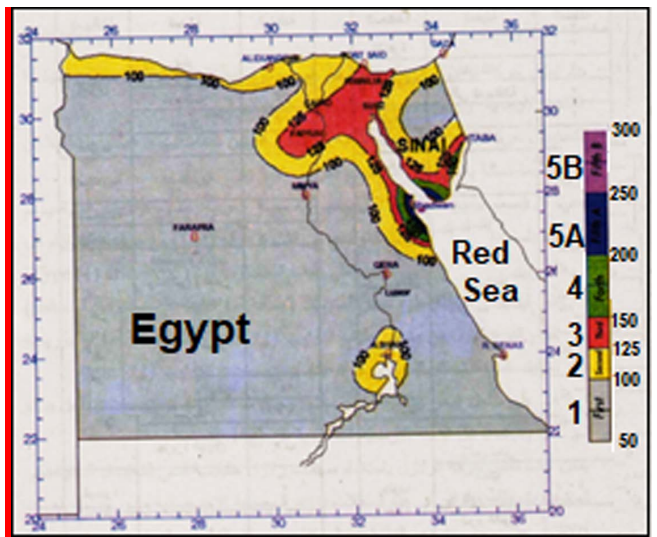

Figure 8. Seismic activity zones in Egypt, after (Egyptian Code, Part 6, 2001).

Table 4. Seismic effect zones for cities in Egypt (Egyptian Code, Part 6, 2001).

\begin{tabular}{|c|c|c|c|c|c|}
\hline Governorate & City & Zone & Governorate & City & Zone \\
\hline \multirow{3}{*}{ Aswan } & Edfo & 1 & \multirow{3}{*}{ Cairo } & & \\
\hline & Kom Ambo & 2 & & & 3 \\
\hline & Aswan & 3 & & & \\
\hline \multirow{2}{*}{ Assuit } & & \multirow{2}{*}{1} & \multirow{2}{*}{ Alkaliobia } & Kafr shoukr & 2 \\
\hline & & & & The Rest & 3 \\
\hline Alexandria & Alexandria & 2 & Almonoufia & & 2 \\
\hline Ismailia & & 3 & Minia & & 1 \\
\hline Luxor & & 1 & Alwadi algadeed & & 1 \\
\hline \multirow{4}{*}{ Red Sea } & Quseir, Halaib \& shalateen & 3 & \multirow{4}{*}{ Bani Suif } & \multirow{2}{*}{ Alwasta } & \multirow{2}{*}{3} \\
\hline & Ras Gharib-Safaga & 4 & & & \\
\hline & Hurghada & $5 \mathrm{~A}$ & & \multirow{2}{*}{ The Rest } & \multirow{2}{*}{2} \\
\hline & Shedwan Illand & $5 \mathrm{~B}$ & & & \\
\hline Albehaira & & 2 & Port said & & 3 \\
\hline \multirow{4}{*}{ Giza } & & \multirow{4}{*}{$2 \& 3$} & \multirow{4}{*}{ South Sinai } & Abu Redis-Ras Sedr & 3 \\
\hline & & & & Dahab-altor & 4 \\
\hline & & & & Sharm alshikh-Noibaa & $5 \mathrm{~A}$ \\
\hline & & & & Taba & $5 \mathrm{~B}$ \\
\hline Aldakahlia & & 2 & Domiatt & & 2 \\
\hline Suez & Suez & 3 & Sohag & & 1 \\
\hline \multirow[t]{2}{*}{ Alsharqia } & $\begin{array}{l}\text { Belbis-Abu Hamad, } \\
10^{\text {th }} \text { of Ramadan }\end{array}$ & 2 & \multirow[t]{2}{*}{ North Sinai } & & \multirow[t]{2}{*}{2,3} \\
\hline & The Rest & 3 & & & \\
\hline \multirow[t]{2}{*}{ Algharbia } & & 2 & Qena & & 1 \\
\hline & & & Kafr Alshikh & & 2 \\
\hline \multirow[t]{2}{*}{ Fayoum } & & 3 & \multirow{2}{*}{ Marsa Matrouh } & Marsa Matrouh & 2 \\
\hline & & & & Saloum & 2 \\
\hline
\end{tabular}


$\mathrm{cm}$ was less than 15 (ranging from 9 to 10) at the first two meter depth according (Egyptian Code, Part 2, 2001) (where the minimum drill depth of the shallow foundations must not be less than $0.8 \mathrm{~m}$ ) and the cohesion values of the sand soil was less than $70 \mathrm{KN} / \mathrm{m}^{2}$ (equal to zero) as well as Vs-values were less than 180 $\mathrm{m} / \mathrm{s}$ (ranging from 155 to $176 \mathrm{~m} / \mathrm{s}$ ), see Table 6 . Based on the determined soil layer type (class $D$ ), the earthquakes factors including $S, T_{B}, T_{C}$, and $T_{D}$ were $1.80,0.10,0.30$, and 1.20 respectively (Table 7). According to Egyptian code for vibration and dynamic load foundations, the studied project area was classified as low potential seismic.

Table 5. Values of design ground acceleration $\left(\mathrm{a}_{\mathrm{g}}\right)$ and seismic zones (Egyptian Code, Part 6, 2001).

\begin{tabular}{cc}
\hline Zone & Value of design ground acceleration $\left(\mathrm{a}_{\mathrm{g}}\right)$ \\
\hline First & 0.100 \\
Second & 0.125 \\
Third & 0.150 \\
Forth & 0.200 \\
Fifth A & 0.250 \\
Fifth B & 0.300 \\
\hline
\end{tabular}

Table 6. Soil layers classification under foundations (Egyptian Code, Part 6, 2001).

\begin{tabular}{|c|c|c|c|c|}
\hline $\begin{array}{c}\text { Soil } \\
\text { classification }\end{array}$ & Description of soil & $\begin{array}{l}\mathrm{N}_{\text {spt }} \text { Number } \\
\text { of blow/30 cm }\end{array}$ & $\mathrm{C}_{\mathrm{u}}\left(\mathrm{KN} / \mathrm{m}^{2}\right)$ & Vs $(\mathrm{m} / \mathrm{s})$ \\
\hline A & $\begin{array}{l}\text { Rock or rock fragments resembling contain a week surface layer have a } \\
\text { thickness of at most } 5 \mathrm{~m} \text {. }\end{array}$ & - & - & More than 800 \\
\hline B & $\begin{array}{l}\text { Deposits extends for tens of meters thick composed of (sand + gravel) dense } \\
\text { or clay with heavy resistance cohesion } \mathrm{C}_{\mathrm{u}} \text { shown in the table, with the } \\
\text { increasing values of mechanical properties gradually with depth. }\end{array}$ & More than 50 & More than 250 & $360-800$ \\
\hline $\mathrm{C}$ & $\begin{array}{l}\text { Deep soil deposits of non-cohesive (sand }+ \text { gravel) medium to heavy or clay } \\
\text { with resistance cohesion } \mathrm{C}_{\mathrm{u}} \text { shown in the table, thickness ranges from tens to } \\
\text { hundreds of meters. }\end{array}$ & $15-50$ & $70-250$ & $180-360$ \\
\hline $\mathrm{D}$ & $\begin{array}{l}\text { Soil is non-cohesive (sand, gravel) loose to medium density (may be present } \\
\text { by cohesive layers such clay, loam or the prevailing coherent soil with } \\
\text { cohesion resistance } \mathrm{C}_{\mathrm{u}} \text { shown in the table. }\end{array}$ & Less than 15 & Less than 70 & Less than 180 \\
\hline $\mathrm{E}$ & $\begin{array}{l}\text { Soil section consists of the surface layer of river sediment Vs, such C or D } \\
\text { with variable thickness from } 5-20 \text { m and the material underneath are } \\
\text { strongest Vs more than } 800 \mathrm{~m} / \mathrm{s}\end{array}$ & - & - & - \\
\hline
\end{tabular}

Table 7. Earthquakes factors based on subsoil class (Egyptian Code, Part 6, 2001).

\begin{tabular}{ccccc}
\hline Subsoil Class & $\mathrm{S}$ & $\mathrm{T}_{\mathrm{B}}$ & $\mathrm{T}_{\mathrm{C}}$ & $\mathrm{T}_{\mathrm{D}}$ \\
\hline $\mathrm{A}$ & 1.00 & 0.05 & 0.25 & 1.20 \\
$\mathrm{~B}$ & 1.35 & 0.05 & 0.25 & 1.20 \\
$\mathrm{C}$ & 1.50 & 0.10 & 0.25 & 1.20 \\
$\mathrm{D}$ & 1.80 & 0.10 & 0.30 & 1.20 \\
\hline
\end{tabular}




\section{Estimation of Allowable Bearing Capacity of the Study Soils}

According to the Egyptian code of shallow foundations, (in case of dry soil where pore water pressure equal to zero as in the present study area) allowable bearing capacity of the studied medium to dense sand at the designed drill depth of the shallow foundations (not less than $0.8 \mathrm{~m}$ depth) was ranging from 1.5 to 3 $\mathrm{kg} / \mathrm{cm}^{2}$ (at shallow foundation wide must not be less than $1 \mathrm{~m}$ ). Table 8 showed the allowable bearing capacity according to (Egyptian Code, Part 3, 2001) in dry conditions for the soils.

\section{Conclusions and Recommendations}

\subsection{Conclusions}

The studied soils are representative of pre-Nile sands named Qena Sand Formation (Pleistocene age). The scope of the present work was the estimation of the geotechnical parameters of the studied soils including gradation parameters, shear wave velocities, and shear parameters to determine the earthquakes factors, the design ground acceleration, and the allowable bearing capacity of the studied soils. The estimation of earthquakes factors of the studied soils was to determine the seismic suitability of the studied area to construct poultry feed factory at the industrial Qift city, Qena, Egypt. The earthquakes factors are including soil coefficient (S), limits of constant value for elastic response spectrum $\left(\mathrm{T}_{\mathrm{B}}\right.$ and $\mathrm{T}_{\mathrm{C}}$ ), and specified value for begin of the constant displacement spectrum $\left(T_{D}\right)$. These earthquakes factors help the civil engineer to calculate the total base shear due to earthquakes (if happened) to design the project foundations and to avoid the possible seismic damages. To achieve these objectives, fifty disturbed samples were collected from five wash mechanical drilling boreholes $(10 \mathrm{~m}$ depth). Grain size analyses, shear wave velocity, direct shear box, and standard penetration tests were carried out on the studied sand samples.

The results of the grain size analysis test of the studied soils showed that the sands samples at the five studied boreholes were classified as poorly graded

Table 8. Allowable bearing capacity values according to (Egyptian Code, Part 3, 2001).

\begin{tabular}{|c|c|c|c|}
\hline Soil type & Description & $\begin{array}{l}\text { Allowable bearing } \\
\text { capacity }\left(\mathrm{Kg} / \mathrm{cm}^{2}\right)\end{array}$ & Notes \\
\hline \multirow{3}{*}{$\begin{array}{c}\text { Gravel or mixtures of gravel and } \\
\text { sand }\end{array}$} & High compacted & $5-7$ & \\
\hline & Medium compacted & $4-6$ & \\
\hline & Loose & $2-4$ & \\
\hline \multirow{3}{*}{$\begin{array}{l}\text { Coarse to medium sand or } \\
\text { mixture of sand with little gravel }\end{array}$} & Very dense & $3-5$ & \\
\hline & Medium to Dense & $1.5-3$ & $\begin{array}{l}\text { Foundation wide must } \\
\text { be not less than } 1 \mathrm{~m}\end{array}$ \\
\hline & Loose & $1-2$ & \\
\hline \multirow{3}{*}{$\begin{array}{l}\text { Fine to medium sand or clayey } \\
\text { or silty sand }\end{array}$} & Very dense & $2-4$ & \\
\hline & Medium to Dense & $1.5-2.5$ & \\
\hline & Loose & $1-1.5$ & \\
\hline
\end{tabular}


sands (SP) at the first two meters depth where the gradation parameters of the studied sands including coefficient of uniformity were less than 6 according to USCS. But the sands collected from two meter to ten meter depth were classified as well graded sands (SW) where the gradation parameters of the studied sands including coefficient of uniformity were more than 6 according to USCS. SPT-test results pointed to that the surface loose poorly graded sands (at the first two meters depth) have the lowest values ranging from 9 to 10 . SPT-values were increased with increasing the depth and the compaction of the sands. The greatest values were ranging from 30 to 45 at about 8 to 10 meters depth and described as dense sands. Some intermediate SPT-values were ranging from 10 to 30 and described as medium dense sands (at depth ranging from 3 to 7 meters). The results of the shear wave velocity tests illustrated that Vs-values were ranging from 155 to $176 \mathrm{~m} / \mathrm{s}$.

The results of direct shear box tests showed that the friction angle values of the studied sandy soils range from $32^{\circ}$ to $40^{\circ}$. The frictional angels of the sand at $\mathrm{B} 2, \mathrm{~B} 3$, and $\mathrm{B} 4$ were $32^{\circ}, 35^{\circ}$, and $40^{\circ}$ respectively. The results showed also that the cohesion values $(\mathrm{Cu})$ of the studied sandy soils equal to zero. According to Egyptian code for vibration and dynamic load foundations, the studied area is located in the first seismic zone (zone no. 1). The $\mathrm{a}_{\mathrm{g}}$-value is 0.10 and the earthquakes factors including $S, T_{B}, T_{C}$, and $T_{D}$ were $1.80,0.10,0.30$, and 1.20 respectively that means the studied project area was classified as low potential seismic, so that the potential for liquefaction of the soils at the study area is negligible during seismic shaking (if happened). According to the Egyptian code of shallow foundations, (in case of dry soil and the pore water pressure equal to zero as in the present study area) the allowable bearing capacity of the studied sand medium to dense at the designed drill depth of the shallow foundations (not less than $0.8 \mathrm{~m}$ depth) was ranging from 1.5 to $3 \mathrm{~kg} / \mathrm{cm}^{2}$.

\subsection{Recommendations}

1) Shallow foundations either isolated footing or structural mat are recommended. According to the Egyptian code for shallow foundations, it is recommended that, the minimum drill depth of the shallow foundations must not be less than $0.8 \mathrm{~m}$.

2) Compaction of the studied sands is recommended to obtain at least eighty seven percent of the maximum modified proctor density value.

\section{Acknowledgements}

Greatly thanks to the owner of the poultry feed factory project for valuable cooperation.

\section{Conflicts of Interest}

The author declares no conflicts of interest regarding the publication of this paper. 


\section{References}

Abd El-Rahman, M. A. (1980). Geology of the Area Southeast of Qena with Special Reference to Phosphate Deposits. M.Sc. Thesis, Assiut: Assiut University.

Abd El-Razik, T. M., \& Razvaliaev, A. V. (1972). On the Tectonic Origin of the Nile Valley between Idfu and Qena. Egyptian Journal of Geology, 2, 235-244.

Abdalla, A. M., Abu-Khadrah, A. M., \& Abd El-Razik, T. M. (1977). New Light on the Geologic Structure of East Qena Region, Upper Egypt. In Proceeding of the VI Colloquim on the Geology of the African Region (pp. 767-778). Athens, II.

Basher, A. A. (2003). Application of Geophysical Techniques at New Qena City, Qena, Egypt. M.Sc. Thesis, Qena: South Valley University.

Deif, A., Hamed, H., Igrahim, H. A., Abou Elenean, K., \& El-Amin, E. M. (2011). Seismic Hazard Assessment in Aswan, Egypt. Journal of Geophysics and Engineering, 8, 531-548. https://doi.org/10.1088/1742-2132/8/4/006

Egyptian Code (2001) Egyptian Code of Soil Mechanics, Foundations Carrying Out and Designation, Part 2 (6th ed.). Laboratory Tests.

Egyptian Code (2001) Egyptian Code of Soil Mechanics, Foundations Carrying Out and Designation, Part 6 (6th ed.). Vibration and Dynamic Load Foundations.

Egyptian Code (2001) Egyptian Code of Soil Mechanics, Foundations Carrying Out and Designation, Part 3 (6th ed.). Shallow Foundations.

Egyptian Geological Survey \& Minning Authority (1978). Geological Map of Qena Quadrangle, Egypt, Scale 1:500,000.

El-Etr, H. A., Yousif, M. S. M., \& Dardir, A. A. (1979). Untilization of (Landsat) Images and Conventional Aerial Photographs in the Delineation of Some Aspects of Geology of Central Eastern Desert, Egypt. Annals of the Geological Survey of Egypt, IX, 136-162.

Hermina, M. H., \& Issawi, B. (1969). Rock Stratigraphic Classification of Upper Cretaceous-Lower Tertiary Exposures in Southern Egypt. Symposium on the Geology of Libya, University of Tripoli, 147-154.

Ismaiel, H. A. H. (2013). Cement Kiln Dust Chemical Stabilization of Nile Silt Soil Exposed Along Nile Banks at Taramsa Village, Qena Region, Egypt. International Journal of Scientific \& Engineering Research, 4, 1428-1437.

Ismaiel, H. A. H., Askalany, M. M., \& Badry, M. M. (2011). Geotechnical Propertied and Classification of Both Non-Expansive and Expansive Soils Exposed along the New Upper Egypt-Red Sea Road, Eastern Desert, Egypt. Scientific Journal of Banha University, $6,1-18$.

Ismaiel, H. A. H., Makhloof, A. A., Mahmoud, A. A., \& Galal, A. A. (2012). Geotechnical Behavior of Pliocene Sedimentary Rocks Exposed along Qena-Safaga Road at Qena Region, Egypt. International Mining Engineering and Mineral Processing, 1, 84-93.

https://doi.org/10.5923/j.mining.20120102.10

Ismail, I. S. (2000). Application of Geophysical Techniques for Engineering Purposes and Delineating the Underground Water at New Tiba City, Luxor, Egypt. Ph.D. Thesis, Qena: South Valley University.

Issawi, B. (1972). Review of the Upper Cretaceous-Lower Tertiary Stratigraphy in Central and Southern Egypt. AAPG Bulletin, 55, 1448-1463.

Issawi, B., Abdallah, A. M., \& Said, M. (1978). Geology of Wady El-Mashash Area. Eastern Desert, Egypt, 8, 163-185.

Krasheninnikov, V. A., \& Penikarov, V. P. (1964). Zonal Stratigraphy of Paleogene in the 
Nile Valley (No. 32, p. 26). Cairo: Geol. Survey an Min., Res. Dep.

Makhloof, A. A., Mahmoud, A. A., Ismaiel, H. A. H., \& Galal, A. A. (2013). Evaluation and Interpretation of Cracks along Qena-Safaga Road Using Surveying Techniques. Minia Journal of Engineering and Technology, 32, 194-203.

Mostafa, T., Abd el-aziz, K., \& Gad-Elkareem, A. M. (2016). Ambient Noise for Determination of Site Dynamic Properties at Hurghada and Safaga Cities, Red Sea, Egypt. Acta Geodynamica et Geomaterialia, 13, 227-240.

Philiobbos, E. R. (1969). Geology of the Phosphorites of the Nile Valley. PhD Thesis, Assiut: Assiut Uniersity.

Sabry, H. (1968). Stratigraphy and Classification of Type Esna Group of Egypt. AAPG Bulletin, 52, 1792-1793.

Said, R. (1962). The Geology of Egypt (p. 337). Amsterdam, New York: Elsevier Pub. Co.

Said, R. (1971). Exploration Notes to Accompany the Geological Map of Egypt (No. 56, p. 123).

Said, R., \& Sabry, H. (1964). Planktonic Foraminifera from the Type Location of Esna Shale in Egypt. Micro-Paleontology, 10, 375-395. https://doi.org/10.2307/1484585

Sawires, R., Pelaez, J. A., Fat-Helbary, R. E., \& Ibrahim, H. A. (2016). A Review of Seismic Hazard Assessment Studies and Hazard Description in the Building Codes for Egypt. Acta Geodaetica et Geophysica, 51, 151-180. https://doi.org/10.1007/s40328-015-0117-5

Wuest, R. A. J., \& McLane, J. (2000). Rock Deterioration in the Royel Tomb of Seti I, Valley of the Kings, Luxor, Egypt. Engineering Geology, 58, 163-190. https://doi.org/10.1016/S0013-7952(00)00057-0

Yesiller, N., Hanson, J. L., Rener, A. T., \& Usmen, M. A. (2001). Ultrasonic Testing for Evaluation of Stabilized Mixtures, Geomaterials. Transportation Research Record, 1757, 32-39. https://doi.org/10.3141/1757-04

Youssef, A. M., Pradhan, B., Gaber, A. F. D., \& Buchroithner, M. F. (2009). Geomorphological Hazard Analysis along the Egyptian Red Sea Coast between Safaga and Quseir. Natural Hazards and Earth System Sciences, 9, 751-766.

https://doi.org/10.5194/nhess-9-751-2009 